Family Profile No. 14, 2018

\title{
First Marriage Rate in the U.S., 2016
}

\section{Author: Krista K. Payne}

Since 1970, the overall marriage rate (defined as the number of marriages per 1,000 unmarried women 15 and older) in the United States has declined. In recent years, however, it has remained fairly stable, reaching 31.9 in 2016 (FP-17-25). The thirty-five year decline in the marriage rate has been accompanied by a rising age at first marriage (FP-16-07) and a greater share of Americans never marrying (Goodwin, McGill, \& Chandra 2009). The overall marriage rate includes those entering both first and remarriages. Since $70 \%$ of marriages are first marriages (FP-12-21), it is important to consider first and remarriages separately. This family profile is an update to FP-16-18, FP-14-08, FP-11-12, and FP-10-05.

\section{Trends in the First Marriage Rate}

- The first marriage rate declined from 49.8 first marriages (per 1,000 never-married women) in 2008 to 43.1 in 2013.

- The first marriage rate rose in 2014 and has remained essentially unchanged over the last three years, at 45.2 in 2016.

- In 2016, an estimated 1,657,583 women entered a first marriage.

\section{First Marriage Rate by Race and Ethnicity}

- In 2016, the first marriage rate was highest for Asian women (65.1).

- Black women experienced a lower first marriage rate (20.6) than the other racial/ethnic groups considered here.

- A nativity gap exists among Hispanics; foreign-born had a higher first marriage rate (57.7) than nativeborn (42.0).

Figure 1. First Marriage Rate for Women 18 and Older, 2008-2016

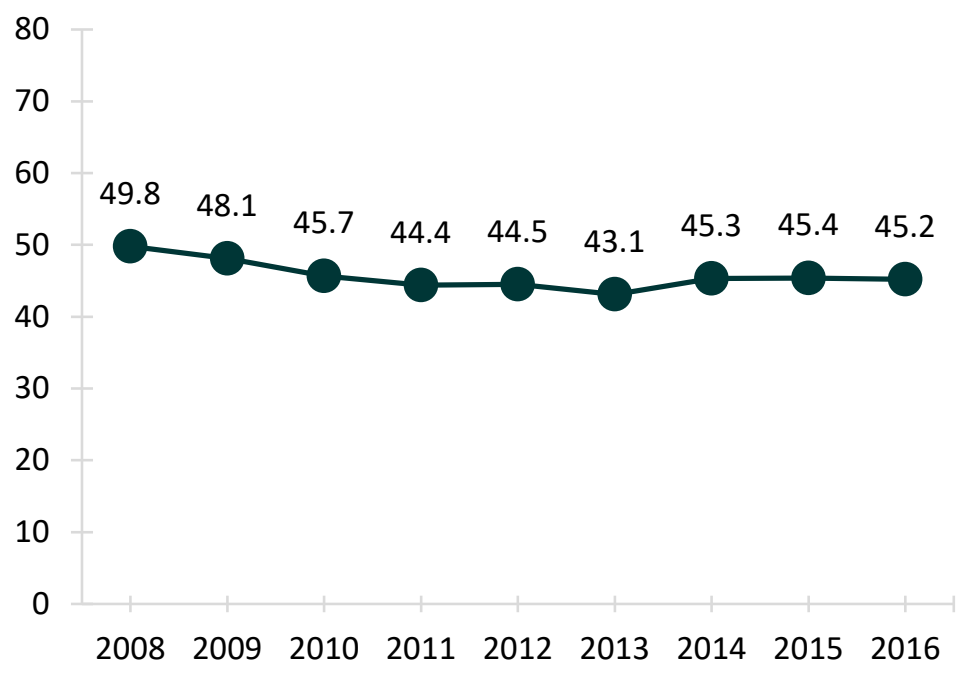

Source: NCFMR analyses of U.S. Census Bureau, American Community Survey, 1-yr. est., 2016.

Figure 2. First Marriage Rate for $\mathrm{W}$ omen 18 and Older by Race and Ethnicity, 2016

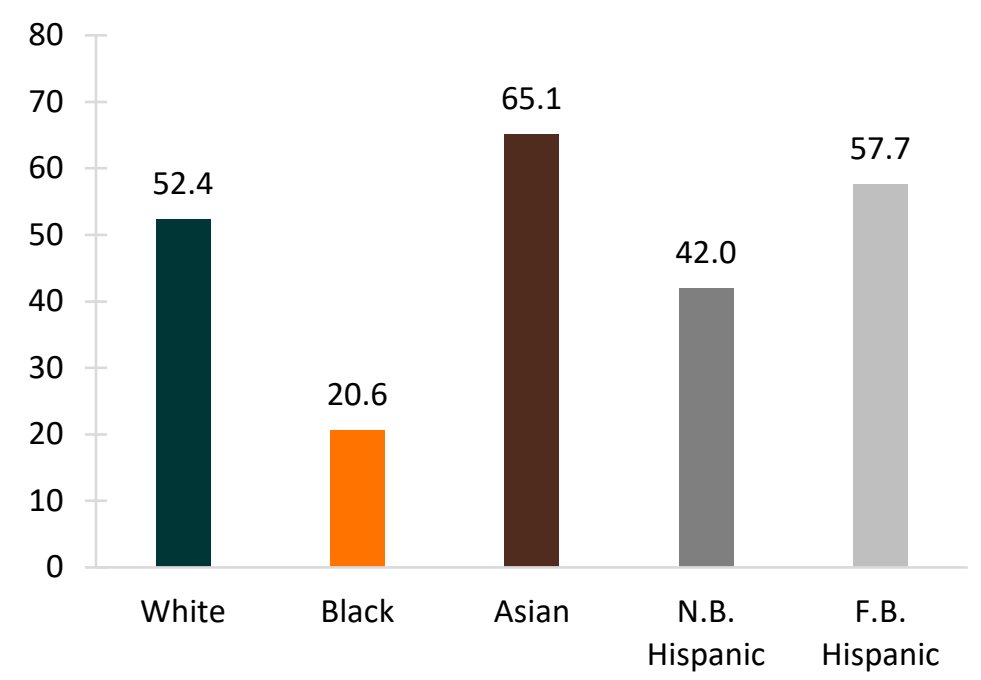

Source: NCFMR analyses of U.S. Census Bureau, American Community Survey 1-yr est., 2016.

Note: N.B. represents Native Born and F.B. represents Foreign Born. 
- Women with a bachelor's degree or higher had a substantially higher first marriage rate (70.8) than women without a college degree. This rate is twice as high as experienced by women with a high school degree.

- The first marriage rate was fairly similar among women with a high school degree (34.5) or some college (39.1). The lowest rate occurred among women with less than a high school education (29.7).
Figure 3. First Marriage Rate for Women 18 and Older by Educational Attainment, 2016

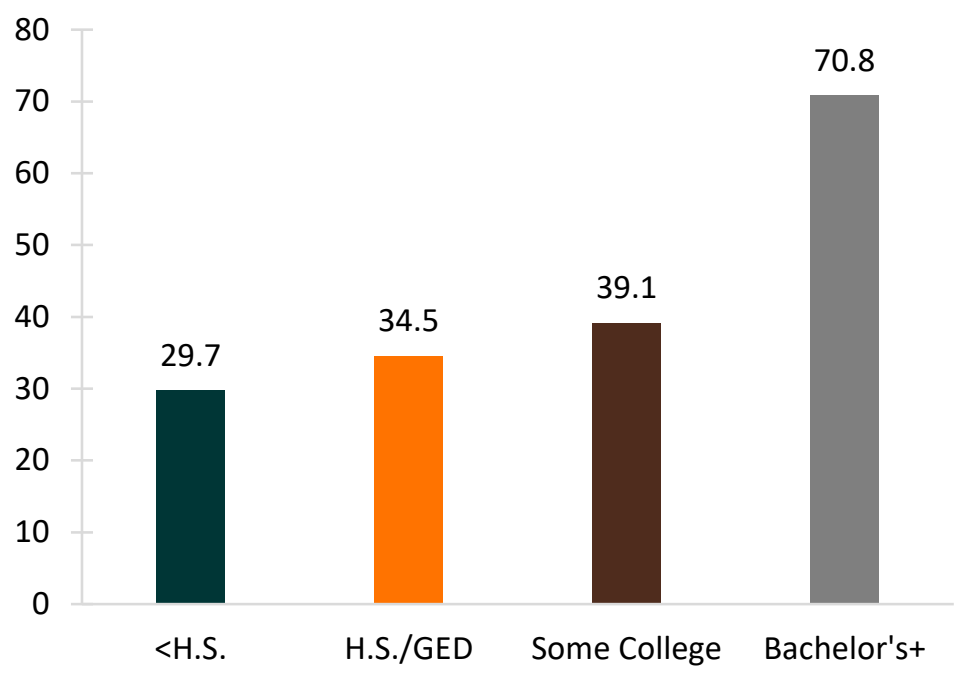

Source: NCFMR analyses of U.S. Census Bureau, American Community Survey, 1-yr. est., 2016.

\section{First Marriage Rate Remains Steady at about

\section{References:}

L. R. (2016). First marriage rate in the U.S., 2014. Family Profiles, FP-16-18. Bowling Green, OH: National Center for Family \& Marriage Research. https://www.bgsu.edu/ncfmr/resources/data/family-profiles/anderson-first-marriage-rate-2014-fp-16-18.html

Anderson, L. R. \& Payne, K. K. (2016). Median age at first marriage, 2014. Family Profiles, FP-16-07. Bowling Green, OH: National Center for Family \& Marriage Research. http://www.bgsu.edu/content/dam/BGSU/college-of-arts-and-sciences/NCFMR/documents/FP/anderson-payne-median-age-firstmarriage-fp-16-07.pdf

Cruz, J. (2012). First marriage vs. remarriage in the U.S., 2010. Family Profiles, FP-12-21. Bowling Green, OH: National Center for Family \& Marriage Research. http://www.bgsu.edu/content/dam/BGSU/college-of-arts-and-sciences/NCFMR/documents/FP/FP-12-21.pdf

Goodwin, P., McGill, B., \& Chandra, A. (2009). Who marries and when? Age at first marriage in the United States: 2002. NCHS Data Brief, no 19. Hyattsville, MD: National Center for Health Statistics.

Hemez, P. (2017). Marriage rate in the U.S.: Geographic variation, 2016. Family Profiles, FP-17-25. Bowling Green, OH: National Center for Family \& Marriage Research. https://www.bgsu.edu/ncfmr/resources/data/family-profiles/hemez-marriage-rate-2016-fp-17-25.html

Payne, K. K. \& Gibbs, L. (2011). First marriage rate in the U.S., 2010. Family Profiles, FP-11-12. Bowling Green, OH: National Center for Family \& Marriage Research. http://www.bgsu.edu/content/dam/BGSU/college-of-arts-and-sciences/NCFMR/documents/FP/FP-11-12.pdf

Payne, K. K. (2010). Rate of first marriage in the U.S., 2008. Family Profiles, FP-10-05. Bowling Green, OH: National Center for Family \& Marriage Research. http://www.bgsu.edu/content/dam/BGSU/college-of-arts-and-sciences/NCFMR/documents/FP/Fp-10-05.pdf

Stykes, B., Payne, K. K., \& Gibbs, L. (2014). First marriage rate in the U.S., 2012. Family Profiles, FP-14-08. Bowling Green, OH: National Center for Family \& Marriage Research. http://www.bgsu.edu/content/dam/BGSU/college-of-arts-and-sciences/NCFMR/documents/FP/FP-14-08-marriage-rate-2012.pdf

\section{Suggested Citation:}

Payne, K. K. (2018). First marriage rate in the U.S., 2016. Family Profiles, FP-18-14. Bowling Green, OH: National Center for Family \& Marriage Research. https://doi.org/10.25035/ncfmr/fp-18-14.

\begin{tabular}{|c|c|c|}
\hline BCSU. & $\begin{array}{l}\text { National Center for } \\
\text { Family \& Marriage Research }\end{array}$ & $\begin{array}{l}\text { http://www.bgsu.edu/ncfmr } \\
\text { ncfmr@bgsu.edu }\end{array}$ \\
\hline BOWLING GR & EEN STATE UNIVERSITY & (419) 372-3119 \\
\hline
\end{tabular}

